\title{
Endring i mestringstillit hos sykehusleger etter kurs i klinisk kommunikasjon
}

\author{
Sammendrag \\ Bakgrunn. Klinisk kommunikasjon \\ i spesialisthelsetjenesten har vært \\ lite undersøkt vitenskapelig. Et ameri- \\ kanskutviklet kurs i klinisk kommuni- \\ kasjon ble prøvd ut i et stort norsk \\ sykehus. I denne delstudien ville vi \\ undersøke i hvilken grad legene endret \\ tillit til egne ferdigheter i løpet av \\ kurset.
}

\begin{abstract}
Materiale og metode. Leger under 60 år i Akershus universitetssykehus med arbeid $\mathrm{i}$ en klinisk somatisk avdeling kunne inkluderes. Deltakerne fylte ut et validert spørreskjema før og rett etter kurset, med hovedvekt på gradering av mestringstillit (tillit til egen mestring av spesifikke kommunikasjonsferdigheter) på en tipunkts skala for ni viktige kommunikative ferdigheter.
\end{abstract}

Resultater. 103 tilfeldig trukne leger ble forespurt om å delta, 62 gjennomførte kurset, som var på 20 timer.

Deltakerne endret oppfatning i positiv retning når det gjaldt troen på at kommunikasjon kan læres ved denne typen kurs. Mestringstilliten endret seg også i positiv retning. Endringen var beskjeden (i gjennomsnitt 0,6 poeng på tipunkts skala), men statistisk signifikant for sju av de ni ferdighetene. 41 leger hadde økt og ti leger redusert mestringstillit etter kurset. De sistnevnte var likevel positive til læringseffekt av slike kurs etter å ha gjennomgått dette kurset. Effektene var ikke avhengig av legens kjønn, alder, posisjon (overlege eller underordnet), mestringstillit før kurset eller spesialitet. Av ferdighetene det ble undervist $i$, var det den å vise empati som færrest deltakere ville trene på etter kurset.

Fortolkning. Et kort kurs om kommunikative ferdigheter for sykehusleger fører til noe bedret mestringstillit hos deltakerne. Om de observerte forandringen gir seg utslag i bedret klinisk kommunikasjon, er gjenstand for pågående forskning.

\section{Pål Gulbrandsen}

pal.gulbrandsen@ahus.no

Helse Sør-Øst kompetansesenter for

helsetjenesteforskning

Akershus universitetssykehus

og

Fakultetsdivisjon Akershus universitetssykehus Universitetet i Oslo

\section{Bård Fossli Jensen}

Helse Sør-Øst kompetansesenter for

helsetjenesteforskning

Akershus universitetssykehus

\section{Arnstein Finset}

Avdeling for atferdsfag

Institutt for medisinske basalfag

Universitetet i Oslo

De siste 30 årene har det vært tiltakende interesse for kommunikasjonen mellom lege og pasient, og en rekke studier har ført til at vi i dag har mye kunnskap om hva som er de viktigste elementene i god kommunikasjon (1). Systematisk videofilming av egne konsultasjoner til bruk i veiledningsgrupper for spesialiteten $\mathrm{i}$ allmennmedisin har vært brukt siden slutten av 1980-årene, og emnet omtales på grunnkursene $\mathrm{i}$ allmennmedisin. I den somatiske spesialisthelsetjenesten derimot, er det bare onkologene som har kommunikasjon som obligatorisk del av sitt videre- og etterutdanningsprogram.

I det amerikanske helseforetaket Kaiser Permanente har man over ca. 15 år utviklet systematisk undervisning i klinisk kommunikasjon beregnet på spesialister (2). Opplegget kalles «The four habits approach to effective clinical communication» og dreier seg om å trene på grupper av ferdigheter til de er utviklet til vaner (vane I - Invester i begynnelsen, vane II - Få frem pasientperspektivet, vane III - Vis empati, vane IV Invester $\mathrm{i}$ avslutningen). Et omfattende kurs (fem dager) beregnet på leger med spesielt dårlige kommunikative ferdigheter har vist seg å bedre pasienttilfredsheten (2). Men kanskje vel så viktig er det at disse legene, som var svært skeptiske til kurset, også var meget tilfredse og følte at de var gitt et viktig redskap $i$ arbeidet sitt.

Vi gjennomførte i august 2006 et pilotkurs etter Kaiser Permanente-oppskriften over tre dager med 16 norske deltakere, tre amerikanske og tre norske lærere. Kurset viste at undervisningsopplegget, som i Norge er gitt navnet «Fire gode vaner», med små justeringer også var nyttig for norske sykehusleger (3). I Kaiser Permanentes basisprogram for nye leger blir det gitt 12 timers undervisning. Vi valgte å legge opp til et 20-timers kurs over to dager, noe vi mente ville kunne være akseptabelt i omfang både for sykehusledelse og deltakere.

Kurset ble prøvd ut i en randomisert, kontrollert studie gjennomført ved Akershus universitetssykehus i april 2007-juni 2008. Hovedhensikten med studien var å se om et slikt kurs er tilstrekkelig til å føre til atferdsendring, og dette ble studert gjennom videoanalyser av konsultasjonsatferd. Disse resultatene blir publisert senere.

I forbindelse med gjennomføringen av studien kartla vi legenes erfaringer og synspunkter på egen mestringsevne når det gjaldt klinisk kommunikasjon før og etter kurset. Hensikten med denne delstudien var å undersøke i hvilken grad legene endret tillit til egne ferdigheter i løpet av kurset.

\section{Materiale og metode}

Av 249 leger under 60 år i arbeid i Akershus universitetssykehus per 15.2. 2007 ble 80 av en statistiker tilfeldig trukket ut til å delta i studien, stratifisert på 16 avdelinger (anestesi/intensiv-, barne-, endokrinologisk, gastrokirurgisk, gastromedisinsk, gynekologisk/obstetrisk, hematologisk/onkologisk, hjertemedisinsk, infeksjonsmedisinsk, kar/ thoraxkirurgisk, lungemedisinsk, nevrologisk, nyremedisinsk, ortopedisk, urologisk, øre-nese-hals-) og stilling (overlege, lege i utdanningsstilling). I tillegg ble det trukket ut 51 leger til en erstatningsliste til bruk om noen ikke kunne eller ville delta. Legene ble randomisert til å få kurs sommeren 2007 eller vinteren 2008, og ble undervist i 12 grupper på 4-7 deltakere, samt i plenumssesjoner på inntil 16 deltakere.

Tre av kurslærerne hadde tidligere erfaring med kommunikasjonsundervisning $\mathrm{i}$ varierende omfang og hadde vært hjelpelærere under pilotkurset, de tre hjelpelærerne hadde kjennskap til undervisningsopplegget ved selv å ha deltatt på dette kurset. De seks lærerne hadde én hel dag sammen til felles trening for kurslærerrollen.

\section{Hovedbudskap}

- Klinisk kommunikasjon er i liten grad studert i spesialisthelsetjenesten

- Et 20-timers kurs endret sykehuslegers mestringstillit positivt når det gjaldt klinisk kommunikasjon, uavhengig av alder, kjønn og stillingstype 
Tabell 1 Oversikt over emner i kursprogrammet «Fire gode vaner» om klinisk kommunikasjon

Gjensidig presentasjon og gjennomgang av deltakernes forventninger og skepsis til kurset (1 time)

Diskusjon av videoscene fra en spillefilm ( $1 / 2$ time)

Historikk, oversikt over de fire gode vanene, dokumentasjon for effekter av god kommunikasjon (1 time)

Den første gode vanen - Invester i begynnelsen! (2 timer, hvorav 1 time rollespill i smågruppe)

- Hovedelementer: Hvordan skape god kontakt, hvordan få frem alle relevante bekymringer pasienten har, planlegging av resten av konsultasjonen

Den andre gode vanen - Få frem pasientperspektivet! 2 timer, hvorav 1 time rollespill i smågruppel

- Hovedelementer: Hvilke forestillinger har pasienten om tilstanden/symptomene, hvordan virker de inn på dagliglivet, hvilke forventninger har pasienten til hva legen kan bidra med

Gleder og skuffelser som lege og menneske ( 1 time hvorav $1 / 2$ time i smågruppe)

- Hovedelement: Legene bringes i kontakt med egne følelser gjennom å fortelle om seg selv

Den tredje gode vanen - Vis empati! (2 1/2 time, hvorav 1 time rollespill i smågruppe)

- Hovedelementer: Hvordan bli oppmerksom på og respondere på pasientens følelser, hvordan legge til rette for at de blir et tema når det er viktig, oppmerksomhet på egne reaksjoner og handlingsmønstre

Den fjerde gode vanen - Invester i avslutningen! (2 timer, hvorav 1 time rollespill i smågruppe) - Hovedelementer: Hvordan gi informasjon og knytte den til pasientperspektivet, hvordan sikre at den er forstått, hvordan sikre at pasienten følger opp selv og hvordan avslutte

Trening etter deltakernes ønsker (1 1/4 time med rollespill i smågruppe)

Motivasjon for videre trening, oppsummering, gjennomgang av læring, oppfølgning (1 time)

Undervisningen ble gitt over to dager med til sammen 20 timer. Den besto av omtrent 50/50 fordeling på plenums- og gruppeundervisning. En oversikt over emnene vises i tabell 1. Ved fremmøte fylte deltakerne ut et spørreskjema (4). Spørreskjemaet inneholdt spørsmålet «Tror du man kan bli bedre i kommunikasjon med pasienter ved å delta på et kurs?», med svaralternativene «i høy grad», «i noen grad», «i mindre grad», «nei, slett ikke» og «vet ikke». Legenes tillit til at de ville mestre spesifikke kommunikasjonsferdigheter (mestringstillit (self efficacy)) ble kartlagt ved spørsmålet «Hvor sikker er du på at du på en vellykket måte kan utføre hver av de følgende oppgavene?», der det kunne krysses av på en skala fra 1 (slett ikke sikker) til 10 (svært sikker) på spørsmålene i tabell 2. Et tilsvarende spørreskjema ble fylt ut rett etter kurset. Skjemaene ble samlet inn av en sekretær, men deltakerne har neppe regnet med at deres svar var å betrakte som anonyme siden antallet $\mathrm{i}$ hvert kurs var begrenset. Siste sesjon i kurset besto i at deltakerne måtte fortelle om og skrive ned hvilke(n) av de fire vanene de ville prioritere å trene på i tiden etter kurset.

Det ble gjort frekvensanalyse. Statistiske sammenlikninger av gjennomsnittene ble gjort med t-test for parede observasjoner.

\section{Resultater}

Av de 80 uttrukne legene ble 21 av 26 (14 som ikke ville delta, 12 som ikke kunne delta) erstattet (fem kunne ikke erstattes pga. stratifiseringen). Av de 21 reservene var det ytterligere to som ikke ville delta og tre som ikke kunne delta. To av disse igjen var det mulig å erstatte, slik at i alt 72 leger ble inkludert i studien, hvorav 56 tilhørte det opprinnelige utvalget. Senere kunne ti ikke motta intervensjon (fire pga. arbeidspress, to pga. sykt barn, én pga. egen sykdom, én pga. pappapermisjon, én pga. ny jobb og én pga. annen obligatorisk opplæring som ikke kunne flyttes), slik at det var 62 leger som gjennomgikk kursopplegget. Tabell 3 viser deltakernes karakteristika. Fordelingen etter kjønn, stillingstype, alder og spesialitet i utvalget som gjennomgikk intervensjonen, var ikke signifikant forskjellig fra populasjonen deltakerne ble trukket fra.

Kurset endret deltakernes oppfatning av om det er mulig å lære kommunikasjon gjennom et slikt kurs statistisk signifikant i positiv retning (fig 1). Andelen som mente man i høy grad kunne bli bedre, økte fra $19 \%$ før kurset til $36 \%$ etter, mens andelen med liten tro på et slikt kurs (summen av «i liten grad», «slett ikke» og «vet ikke») falt fra $16 \%$ til $3 \%$. To leger var blitt mye mer positive, 16 leger mer positive og tre mer negative i løpet av kurset, mens 40 hadde uendret oppfatning. Data mangler for fire leger.

Kurset endret også statistisk signifikant deltakernes opplevelse av mestring av sju av de ni forespurte ferdigheter ( $\operatorname{tab} 2)$. Dette gjaldt uavhengig av hvordan legene på forhånd vurderte sine ferdigheter. Bedringen var også uavhengig av om legene på forhånd hadde stor, middels eller liten tro på at et slikt kurs kunne være effektivt. Vi fant ikke noen forskjell knyttet til hvilken smågruppe legene hadde vært undervist $i$.

Vi beregnet samlet endring i mestringstillit for hver lege ved å summere verdiene for de ni ferdighetene før og etter kurset. 41 leger hadde økt og ti redusert mestringstillit. Vi fant ikke forskjeller knyttet til kjønn eller aldersgruppe. Vi fant heller ikke signifikante forskjeller knyttet til spesialitet, men her er tallene små. Fire av de fem som hadde mest negativ utvikling i mestringstillit, var kirurger. Legene med negativ endring i mestringstillit, hadde samme positive endring $\mathrm{i}$ oppfatning av muligheten for å lære kommunikasjon gjennom et slikt kurs som legene med positiv endring i mestringstillit. Av de 62 legene var det fire som ikke ønsket å trene spesifikt på noen av de fire vanene etter kurset. For øvrig ville henholdsvis 37 , 33, 20 og 27 leger trene på vane I, vane II, vane III og vane IV.

Tabell 2 Deltakernes svar på spørsmålet «Hvor sikker er du på at du på en vellykket måte kan utføre hver av de følgende oppgavene?», med avkrysningsmuligheter på en skala fra 1 (slett ikke sikker) til 10 (svært sikker). Gjennomsnitt (standardavvik). N = antall som besvarte spørsmålet både før og etter kurs

Innlede en samtale med en pasient om hans eller hennes bekymringer

Avslutte en konsultasjon med et resymé av problemene og en behandlingsplan

Vurdere symptomer på angst og depresjon

Formidle dårlige nyheter til en pasient

På en passende måte konfrontere en pasient som benekter sykdommen sin

Håndtere at pasient og eventuelt pårørende markerer uenighet med deg som lege

Oppmuntre en pasient til å snakke om sine følelser

Utforske intense følelser hos en pasient, f.eks. sinne

Hjelpe en pasient til å håndtere en usikker situasjon

$\begin{array}{lcccr}N & \text { Før kurs } & \text { Etter kurs } & \text { Endring } & \text { P-verdi } \\ 60 & 7,50(1,37) & 8,03(1,18) & 0,53 & <0,001 \\ 61 & 7,52(1,41) & 7,98(1,23) & 0,46 & 0,003 \\ 60 & 5,82(1,74) & 6,07(1,58) & 0,25 & 0,149 \\ 60 & 6,47(1,81) & 6,98(1,69) & 0,52 & 0,001 \\ 61 & 5,61(1,68) & 6,15(1,58) & 0,54 & 0,015 \\ 60 & 6,25(1,71) & 6,53(1,68) & 0,28 & 0,166 \\ 59 & 6,51(1,44) & 7,17(1,51) & 0,66 & 0,003 \\ 61 & 5,03(1,86) & 6,28(1,57) & 1,25 & <0,001 \\ 61 & 6,48(1,63) & 7,15(1,35) & 0,67 & 0,004\end{array}$




\section{Diskusjon}

Dette er den første studien der man ved designen har forsøkt å inkludere en representativ gruppe sykehusleger innen alle somatiske disipliner, ferdige spesialister og leger under utdanning, til et generelt kurstilbud i klinisk kommunikasjon. Frafallsprosenten var liten (godt under 20) og påvirket ikke fordelingen på kjønn, stillingstype, alder og spesialitet signifikant. Vi ser det som positivt for representativiteten at ni av deltakerne $(15 \%)$ hadde svak, negativ eller indifferent forventning til at kurset kunne gi dem noe, fordi det er uvanlig at svakt motiverte leger overhodet deltar i denne typen studier.

Spørreskjemaet om mestringstillit er brukt i forbindelse med kommunikasjonstrening av onkologer, og er ikke spesifikt beregnet på «Fire gode vaner». Vi brukte det fordi de ferdighetene det spørres etter, er relevante i svært mange ulike situasjoner, fordi skjemaets egenskaper er testet, og fordi det som ble undervist på kurset, er generelle kommunikasjonsferdigheter. Av de kartlagte ferdighetene var det bare det å innlede, det å avslutte, det å oppmuntre til å snakke om følelser og utforske følelser (f.eks. sinne) som det ble trent på i alle grupper. Det ble også øvd på å gi dårlige nyheter i mange grupper. Motsatt ble det å oppdage alvorlig angst eller depresjon ikke spesifikt trent på i noen grupper. Forskjellen i endring mellom de ulike indikatorene antyder at treningen $\mathrm{i}$ grupper har vært av betydning, og at legene gjorde substansielle vurderinger av hvert spørsmål i skjemaet for seg. Det kan anføres mot studiens validitet at legene kan ha vært tilbøyelige til å gi positiv tilbakemelding av hensyn til kurslederne og fordi de ikke kunne regne med anonymitet.

De fleste legene rapporterte bedre mestringstillit etter kurset. Den gjennomsnittlige endringen var imidlertid under halvdelen av 1,3 , som var den man observerte $\mathrm{i}$ en dansk studie av leger og sykepleiere $i$ en barneavdeling. Der varte intervensjonen fem dager (5). Selv om endringen vi fant var statistisk signifikant, er det usikkert hva den innebærer. Følelse av mestring øker jobbtrivselen, og det er vist at pasientens etterlevelse av behandlingen er positivt korrelert til legens jobbtrivsel (6). Ti av legene rapporterte mindre mestringstillit etter kurset. Til tross for dette var de mer positivt innstilt til læringseffekten av et slikt kurs etterpå. Tre av de fem som hadde størst negativ endring, ga i den muntlige evalueringen uttrykk for at kurset hadde gitt flere aha-opplevelser i forhold til egen kommunikasjon, og at dette ble opplevd som nyttig. Negativ endring i mestringstillit kan handle om erkjennelse av forbedringsbehov. Slik erkjennelse er god motivasjon, og det ville nok vært en fordel om disse legene kunne tilbys oppfølging, for eksempel med tilbakemelding basert på videoopptak.

I Kaiser Permanente har de erfart at svakt

Tabell 3 Fordeling etter alder, kjønn, spesialitetsgruppe, stillingstype og tidligere erfaring med kommunikasjonskurs blant kursdeltakerne og i populasjonen de ble trukket fra

$\begin{array}{cc}\begin{array}{c}\text { Sykehusleger totalt } \\ (\mathrm{N}=249)\end{array} & \begin{array}{c}\text { Kursdeltakere } \\ (\mathrm{N}=62)\end{array} \\ \text { Antall }(\%) & \text { Antall }(\%)\end{array}$

Alder

$\begin{array}{lll}40 \text { år eller yngre } & 138(55) & 35 \text { (56) } \\ \text { Over } 40 \text { år } & 111(45) & 27(44)\end{array}$

Kjønn

Kvinner

98 (39)

$28(45)$

Spesialitetsgruppe (inkl. leger i utdanningsstillinger)

Indremedisin

81 (33)

23 (37)

Kirurgi linkl. anestesi/intensiv, ortopedi,

øre-nese-hals)

$95(38)$

$17(28)$

Nevrologi

$26(10)$

8 (13)

Pediatri

27 (11)

$7(11)$

Gynekologi/obstetrikk

$20(8)$

Stillingstype

Overlege

$130(52)$

$32(52)$

Lege i utdanningsstilling

Tidligere kommunikasjonskurs

Antall med slikt kurs

- Hvorav etter medisinstudiet

motiverte leger har tatt godt imot «Fire gode vaner». Vi finner at leger med lave forventninger eller lav mestringstillit på forhånd opplever like stor positiv endring i mestringstillit som leger med høye forventninger og høy mestringstillit. Likedan finner vi ingen kjønns- eller aldersforskjeller, eller forskjeller knyttet til om legene er overleger eller er i utdanningsstilling. Det taler for at nivået kurset er lagt på og metodene som anvendes, er generelt nyttige. Det kan også se ut til at de fungerer godt på tvers av spesialiteter, men her må resultatet tillegges mindre vekt fordi det var forholdsvis få leger $\mathrm{i}$ hver gruppe. Vi understreker at effekt på mestringstillit ikke nødvendigvis innebærer påfølgende atferdsendring. Våre funn tyder på at legene selv opplever at de fikk utbytte av kurset uavhengig av slike faktorer, men vi vet ikke ennå om det har ført til atferdsendring.

Empati, vane III, var den vanen færrest leger oppga at de ville trene bevisst på når de kom tilbake til klinisk arbeid etter kurset. Vi ser flere mulige årsaker til dette. Mange ga

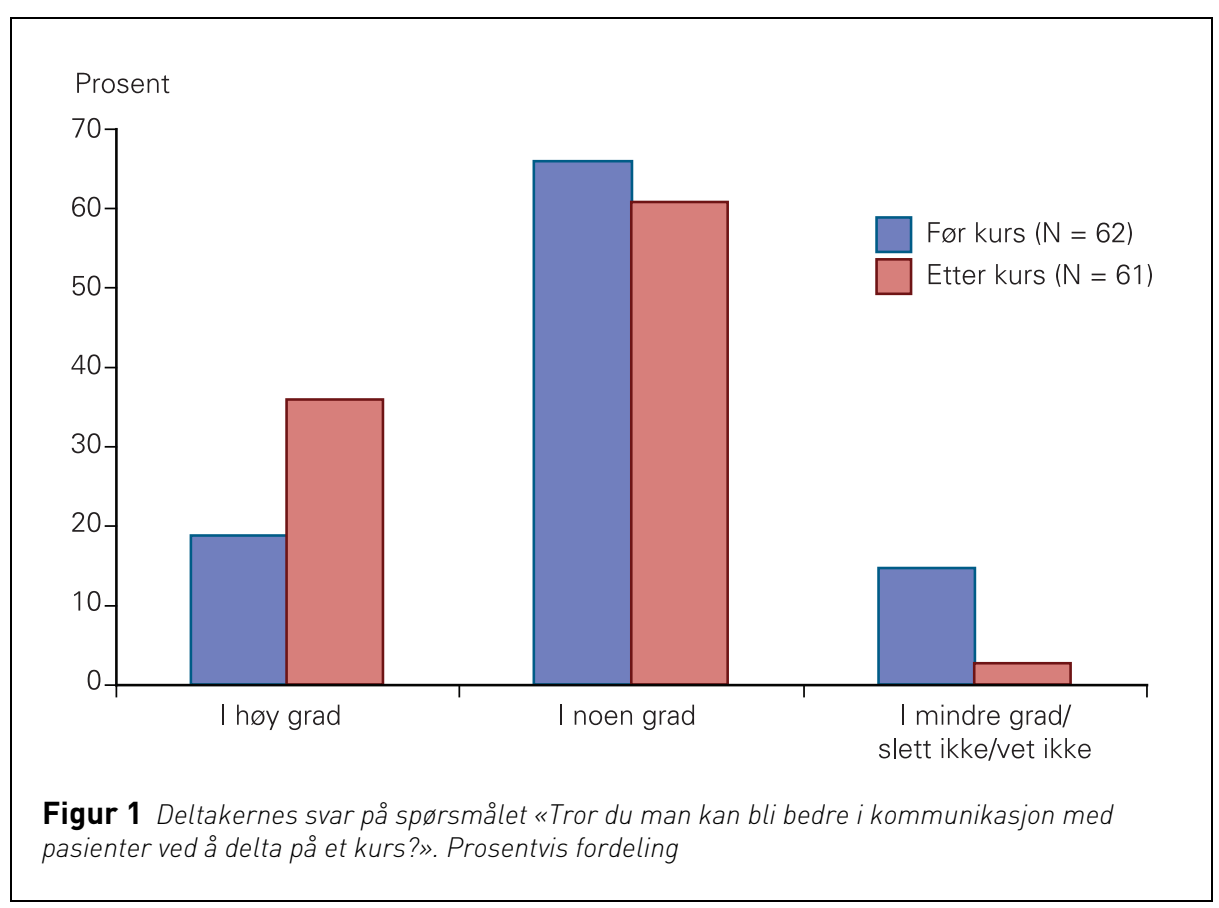


uttrykk for at dette var noe de følte de var gode på allerede. Mange ga også uttrykk for at de ofte viker unna følelsessfæren for å unngå at konsultasjonen drar ut i tid. I kurset legges det derimot vekt på at det ofte skal lite til av empati før det gir god effekt, og at det sjelden fører til tap av tid. Men denne vanen er mindre instrumentell enn de øvrige, og det kan være at vi i mindre grad lyktes med å skape overbevisende rollespill for denne enn for de andre vanene.

Vi takker Reidun Skårerhøgda som foresto all praktisk administrasjon i forbindelse med kursene og lærerne Øivind Ekeberg, Christofer Lundqvist og Petr Ricanek.

Pilotstudien ble finansiert av Den norske legeforenings Utdanningsfond I, Sosial- og helsedirektoratet og Akershus universitetssykehus. Hovedstu- dien ble finansiert av Helse Sør-Øst og Akershus universitetssykehus.

Oppgitte interessekonflikter: Pål Gulbrandsen og Arnstein Finset har satt seg inn i og oversatt det amerikanske undervisningsopplegget, samt tilrettelagt det for norske forhold. De har ikke økonomiske interesser knyttet til opplegget, men har mottatt forelesningshonorarer fra helseforetak Norge og Danmark for å fortelle om det. Institusjonene de representerer har mottatt godtgjørelse for avholdt kurs for en utenlandsk forskningsgruppe som anvender metoden. Bård Fossli Jensen har ingen oppgitte interessekonflikter.

\section{Litteratur}

1. Makoul G. Essential elements of communication in medical encounters: the Kalamazoo consensus statement. Acad Med 2001; 76: 390-3.

2. Stein T. Frankel RM, Krupat E. Enhancing clinician communication skills in a large healthcare organ- ization: a longitudinal case study. Patient Educ Couns 2005; 58: 4-12.

3. Gulbrandsen P, Krupat E, Benth JS et al. «Four Habits» goes abroad: report from a pilot study in Norway. Patient Educ Couns 2008: 72: 388-93.

4. Parle M, Maguire P, Heaven C. The development of a training model to improve health professionals' skills, self-efficacy and outcome expectancies when communicating with cancer patients. Soc $\mathrm{Sci}$ Med 1997: 44: 231-40.

5. Ammentorp J, Sabroe S, Kofoed PE et al. The effect of training in communication skills on medical doctors' and nurses' self-efficacy. A randomized controlled trial. Patient Educ Couns 2007; 66 : $270-7$

6. DiMatteo MR, Sherbourne CD, Hays RD et al. Physicians' characteristics influence patients' adherence to medical treatment: results from the Medical Outcomes Study. Health Psychol 1993: 12 93-102.

Manuskriptet ble mottatt 20.2. 2009 og godkjent 10.9. 2009. Medisinsk redaktør Anne Kveim Lie. 